\title{
Alman Dışişleri Bakanlığı Belgelerinde Türk-Alman İttifakı Yorumlar1 1925-1926
}

\author{
Resul ALKAN*
}

ÖZ

Birinci Dünya Savaşı'nda Türk-Alman ittifakının kilit noktalarında görev almış olan diplomat ve subayların yayınladıkları eserler ve yorumlar 1920'li yıllardan itibaren iki ülke arasında gerçekleşen ortak yakın tarih tartısmalarının ana ekseninde yer almıștır. Birinci Dünya Savașı’nın başlangııında Osmanlı Devleti'nin Berlin Büyükelçisi Mahmud Muhtar Paşa'nın hatıratı ve Gazi Mustafa Kemal Atatürk'ün mülakatı, makalemizin içeriğini oluşturan kaynaklardandır. Hatıratlarında, gerek Mustafa Kemal Atatürk gerekse Muhtar Paşa, Türk-Alman ittifakının dönemin askeri ve politik gelişmeleri dikkate alındığında Osmanlı için kaçınılmaz bir tercih olduğunu, fakat savaş öncesi ittifak kararının Enver Paşa tarafindan tek başına verilmiş olması ve savaşın başlangıcıyla beraber- Osmanlı Devlet adamlarının onayı çervesinde- Osmanlı ordusunun kararlarının Alman askeri heyet mensupları ve generallerin tercihlerine terk edildiğininin ve ordu içerisinde alınan kararların Milli menfaatlere uygun kararlar olmadığının altını çizmektedir. İttifak tartışmalarının iki ülke basını tarafından bir siyasi polemiğe dönüştürülmesine engel olan Alman Büyükelçi Rudolf Nadolny, Türkiye ile Almanya arasında 1920'li yılların ortalarından itibaren gelișmekte olan ekonomik ilişkilerin bu tartısmalardan zarar görmemesi icin özel bir hassasiyet göstermiş ve tartışmaların daha da büyümemesi adına taraflarla yakın ve yapıcı bir diyalog kurmuştur. Makalemizin kapsamında incelenen eserlerden yola çıkarak Türk tarafindan ve Alman tarafindan ortaya atılan iddaları kuruluş aşamasında olan iki ulus devletin tarih yazımının bir parçası olarak yorumlayabiliriz.

Anahtar Kelimeler: Birinci Dünya Savaşı Türk-Alman İttifakı, Mustafa Kemal Atatürk, Mahmud Muhtar Pașa, Alman Dışişleri Bakanlığı, Rudolf Nadolny.

\section{The Turkish-German Alliance Comments in the German Foreign Ministry Documents 1925-1926}

\begin{abstract}
The published works by the diplomats and officers who served at the key points of the Turkish-German alliance in the First World War, took the main axis of the recent discussions since 1920s in both of the countries. The works that make up the content of our article are, the works of Mahmud Muhtar Pasha who was the Berlin Ambassador at the beggining of the First World War and Ghazi Mustafa Kemal Atatürk's memoirs. In their memoirs, both Mustafa Kemal Atatürk and Muhtar Pasha says that the Turkish-German alliance was inevitable for Ottoman considering to the political and military developments, but the decision of the pre-war alliance was given alone by Enver Pasha, and with the beggining of the war Ottoman army's preferences abondoned to the German military delegation members and generals and underlines that the decisions taken within the army are not in line with national interests. German Ambassador Rudolf Nadolny, which prevents the conversion of the alliance debates to a polemic by the press of the two countries, showed a special sensitivity since the mid 1920s developing economic relations between the two countries and established a close and constructive dialogue between them for the controversy does not get further. Based on the works exmined within the scope of our article, we can interpret the claims put forward both by Turkish and German sides as a part of the historiography of the nation states that are in the establishment phase.

Keywords: Turkish-German allience in World War I, Mustafa Kemal Atatürk, Mahmud Muhtar Pasha, , Foreign Ministry of Germany, Rudolf Nadolny.

\section{Giriş}

Türkiye'nin yakın tarihinde gerçekleşen önemli olaylarla alakalı tartsşmalar, günümüzde de devam etmektedir. Gündemde kalan tartışmalı konulardan biri de 1914-1918 Birinci Dünya Savaşı’ndaki TürkAlman İttifakı'dır. İtifakın neden ve nasıl imzalandığına dair tartışmalar üzerine yoğunlaşan akademik çalş̧malar, bugüne kadar süre gelmiştir (Aksakal, 2010; Alkan, 2007; Alkan, 2020; Alkan \& Şimşeki 2018). Birinci Dünya Savaşı yıllarını yaşayan Türk ve Alman ordusu mensupları da Türk-Alman İttifak’’ hakkında değerlendirmelerde bulunmuşlardır (Kannengiesser, 2009; Karabekir, 2001; Mühlmann, 1998; von Sanders, 2006). Makalede, Birinci Dünya Savaşı esnasında, Türk askerî zevatından Gazi Mustafa Kemal Atatürk ve Osmanlı Devleti'nin Berlin Büyükelçisi Mahmud Muhtar Paşa'nın Türk-Alman İttifakı'nı nasıl yorumladıkları ve bu yorumları karşısında Almanya'nın Türkiye Büyükelçisi Rudolf Nadolny'nin yaklaşımı ve ülkesinin Dışişleri Bakanlığı’na ilettiği görüşleri ele alınıyor.
\end{abstract}

\footnotetext{
* Dr. Öğr. Üyesi, Çanakkale Onsekiz Mart Üniversitesi, resulalkan@cumu.edu.tr Makalenin Gönderim Tarihi: 20.04.2020; Makalenin Kabul Tarihi: 07.04.2021
} 
Makalenin yazımında istifade edilen kaynaklarımızın bir kısmı, Nadolny’nin Alman Dışişleri Bakanlığı'na gönderdiği ve Berlin'de bulunan Alman Dișișleri Bakanlığı arșivinde muhafaza edilen yazıșma ve raporlardan oluşmaktadır. Çalışmada yararlanılan diğer önemli kaynaklar ise, 1913-15 yılları arasında Osmanlı Devleti'nin Berlin'deki Büyükelçiliğinde görevinde bulunan Mahmud Muhtar Paşa'nın “Maziye Bir Nazar: Berlin Muahedesi’nden Harbı Umumi’ye kadar Avrupa ve Türkiye-Almanya Münasebatı” isimli hatıratu ile Gazi Mustafa Kemal Atatürk'ün 1926'nın Mart-Nisan aylannda Hakimiyet-i Milliye Başyazarı Falih Rıfkı Atay ve Milliyet Başyazarı Mahmut Soydan ile gerçekleştirdiği mülakatlarıdır.

Çalışmada başlıca cevabı aranan sorular şunlardır: 1920’lerin ortalarında, toplum hafizasının yeniden şekillendirildiği süreç olarak da yorumlayabileceğimiz bu dönemde yakın bir tarihi hadise olarak 1914-1918 Türk-Alman İttifakı Mahmud Muhtar Paşa'nın hatıratı ve Mustafa Kemal Atatürk'ün mülakatında nasıl yorumlanmıştır? Türkiye'de radikal siyasi, ekonomik ve sosyal değişimlerin vuku bulduğu dönemde politik, diplomatik ve askeri nitelikli hatıratlarda Türk-Alman İttifakı'nda hangi motifler öne çıkartılmıştır? Hatıratlarda ortaya atılan iddialar karşısında Alman Büyükelçi Rudolf Nadolny'nin tutumu nasıl olmuştur?

Makalede, konunun mahiyetinin daha iyi anlaşılabilmesi için öncelikli olarak 3 Mart 1924 yllında imzalanan Türk-Alman Dostluk Anlaşması'nı takip eden yıllarda Türk-Alman ilişkilerinin nasıl seyrettiğine dair kısaca bilgi verildikten sonra, çalışmanın ana bölümünde ilgili belgelerde ve hatıralarda Türk-Alman İttifakı'nın hangi noktalarda eleştirildiği sorusuna cevap aranmaya çalışılacaktır. Bunu takip eden son başlıkta ise Mahmud Muhtar Paşa'nın hatıratı ve Mustafa Kemal Atatürk’ün mülakatının yayınlanmasıyla beraber ortaya atılan iddialar sonucunda Alman Büyükelçinin gerçekleştirdiği görüşmeler ile Dıșişleri Bakanlığı'na sunduğu raporlar incelenecektir. Bu çalışma ile iki savaş arası dönemde gelişen Türk-Alman diplomatik ilişkilerini kapsayan araştırmalara, 1920’li yıllardan günümüze aktarılan Atatürk’ün mülakatı ve Mahmud Muhtar Paşa'nın hatıratı özelinde, Birinci Dünya Savaşı'ndaki Türk-Alman İttifakı tarih yazımınına katkı yapılması amaçlanmıştır.

\section{Cumhuriyetin İlk Yıllarında Türk-Alman İlişkileri}

İngiltere, Fransa ve İtalya'nın dahil olduğu galip devletler, savaşı sonlandırmak amacıyla, Almanya ve Osmanlı Devleti ile antlaşmalara imza atmıştır. Osmanlı Devleti ile İtilaf Devletleri arasında 30 Ekim 1918 y1lında imzalanan Mondros Mütarekesi'nin 19. ve 23. maddeleri uyarınca Osmanlı Devleti, müttefiki Alman İmparatorluğu ile her türlü diplomatik ilişkiyi kesip, topraklarında bulunan Alman sivil ve askeri personelin derhal Almanya’ya geri dönmesini sağlayacaktı. Almanların 28 Haziran 1919 tarihinde imzaladığ1 Versailles Antlaşması'nın yükümlülüklerinden bir diğeri ise, Osmanlı Devleti ile arasındaki ilişkilerin yeniden tesisinin antlaşmanın 22. Maddesinin 4. F1krası ve 155., 258., 261. ve 434. Maddeleri uyarınca engellenmesiydi (Koçak, 1991, s. 11).

Birinci Dünya Savaşı sonrasında diplomatik ilişkiler Kasım 1918 ve Mart 1924 tarihleri arasında kesintiye uğramış olsa da, İttihat ve Terakki Cemiyeti'nin liderlerinden Talat Paşa ve Enver Paşa'nın -İtilaf Devletlerinin, özellikle de İngiltere'nin baskılarına rağmen- Alman resmi makamlarının bilgisi, onayı ve himayesinde kısıtlı bir süre Almanya'da bulunmuşlardır. Cemal Paşa'nın ise, Alman tarihçi Sabine Mangold'un tabiriyle "Ehrengast des Stadtkommandanten und des Polizeidirekors von München, yani Münih Garnizon komutanlı̆̆1 ve Emniyet Müdürlüğünün onur konuğu” sifatıyla Mustafa Kemal Atatürk'ün önderliğinde gerçekleşen İstiklal Savaşı'na Berlin ve Münih gibi şehirlerden politik ve askeri destek çabası içerisinde oldukları bilinmektedir (Mangold-Will, 2013, s. 41-66; Hanioğlu, 1995, s. 261-264).

Almanya, Türk-Alman ilişkilerinin temellerinin atıldı̆̆1 ve farklı ülkelerden gelen diplomatların fikir alışveriş imkanı buldugu Lozan Barış görüşmelerine, galip devletlerden gelebilecek muhtemel tepkiyi önlemek adına herhangi bir diplomatını göndermemiştir. Bunun yerine Türkçeye anadili seviyesinde hakim olan Anadolu/Bağdad Demiryolu projesinin eski çalışanlarından, Cumhuriyet Döneminde ise 1926-34 y1llarında İstanbul'da Almanca yayınlanan Türkische Post gazetesinin kurucusu ve genel yayın yönetmenliği görevini icra etmiş olan Franz Frederik Schmidt-Dumont’u Lozan görüşmelerine göndermiştir. Bu suretle Türk heyeti ile dirsek teması kuran Almanlar, Türk delegasyon ile Türk-Alman dostluk antlaşmasının taslağının oluşturulması sonrası, Berlin ve İstanbul'daki iki ülke elçiliklerin yeniden faaliyete geçmesinin gerekliği konusunda sözlü mütabakata varmışlardır (Mangold-Will, 2013, s. 106).

Türk-Alman ilişkilerinin temellerinin atıldığı ve farklı ülkelerden gelen diplomatların fikir alışveriş imkanı bulduğu Lozan Barış görüşmeleri esnasında Almanya’nın galip devletlerden gelebilecek muhtemel 
tepkiyi önleme adına Dışişleri Bakanlığı'ndan bir diplomat yollamak yerine, Türkçeye anadili seviyesinde hakim olan Anadolu/Bagdad Demiryolu projesinin yöneticilerinden, Cumhuriyet Döneminde ise 1926-34 yıllarında İstanbul'da Almanca yayınlanan Türkische Post gazetesinin kurucusu ve genel yayın yönetmenliği görevini icra etmiş olan Franz Frederik Schmidt-Dumont'u Lozan görüşmelerine yollanmıştır. Türk heyeti ile dirsek teması kuran Schmidt-Dumont, Türk delegasyonu ile Türk-Alman dostluk antlaşmasının taslağının oluşturulması sonrası Berlin ve İstanbul'daki iki ülke elçiliklerin yeniden faaliyete geçmesinin gerekliği konusunda sözlü mütabakata varmıştır.

İkili ilişkilerin yeniden kurulması konusunda engel teşkil eden Versailles Antlaşması'nın, 24 Temmuz 1923 tarihinde imzalanan Lozan Barış Antlaşması'yla geçerliliğini yitirmesi ve nihayetinde yaklaşık 8 aylık aranın ardından -Lozan'da Antlaşmayı imzalayan İtilaf Devletleri'nin antlaşmayı parlamentolarında onaylamayı geciktirmesi sonucu- 3 Mart 1924 yllında imzalanan ve aynı yllın 1 Mayıs tarihinde her iki ülke parlamentolarının da onaylanması ile Türk-Alman Dostluk Antlaşması resmiyet kazanmışıtır. Mustafa Kemal Atatürk'ün Kurtuluş Savaşı dönemi silah arkadaşlarından Kemalettin Sami Paşa'nın Berlin’e, 1917 y1lında Bolşeviklerle İttifak Devletleri arasında yürütülen Brest-Litovsk görüşmelerinde bulunan Rudolf Nadolny'nin İstanbul'daki Alman Büyükelçiliği'ne atanmasıyla siyasi, askeri, kültürel ve ekonomik ilişkilerin yeniden kurulması imkânı sağlanmıştır (Alkan, 2011, s. 56-59).

Cumhuriyetin kuruluşunun ilk yıllanında seyreden Türk-Alman politik ilişkilerinde iki önemli nokta dikkat çekmektedir: ilk olarak dış politikada, iki ülkenin Sovyet Rusya ile yakın ilişkiler kurduğu gözlemlenmektedir. Türkiye, 17 Aralık 1925’te, Almanya ise 24 Nisan 1926 tarihinde Sovyetler Birliği ile saldırmazlık ve dostluk antlaşmaları imzalayarak İngiliz emperyalizmine karşı Rusya ile yakınlaşma gerçekleşmiştir (Alkan, 2011; 93-94). Rusya ile olan bu diplomatik yakınlaşmanın bir süreklilik arzetmediği, Türkiye ve Almanya'nın Milletler Cemiyeti’ne üyeliği sürecinde daha net olarak ortaya çıkmıstur. Ruslar her ne kadar iki ülkenin üyeliğine karşı memnuniyetsizliğini dile getirse de, 1926 yllında Almanya ve 1932 yılında Türkiye Milletler Cemiyeti‘ne üye olmuşlardır. Türk-Alman politik ilişkilerinde vurgulanması gereken ikinci önemli nokta ise, başkentin İstanbul'dan Ankara'ya taşınmasında Almanya'nın Türkiye'ye vermiş olduğu diplomatik destektir. Birinci Dünya Savaşı'nın galiplerinden İngiltere, Fransa ve İtalya daimi elçilik binalarının 13 Ekim 1923 'ten itibaren başkent olan Ankara'ya inşa edilmesi konusunda isteksiz davranmakta iken, Alman tarafinın Türk devlet adamlarının bu isteğine ilk olumlu karşıllğı veren ülke olması ve Alman Büyükelçiliğ̈ínin Ankara'da yapımına başlanan ilk elçilik binası olması önem arz etmektedir.

Askeri alandaki ilişkiler, savaş öncesine kıyasla daha az yoğunlukta gerçekleşmekte ise de usulen aynı prensipte devam etmekteydi. Harp Akademisi'lerinde ve Türk Donanma Kuvvetlerinde sembolik saylda Alman subayı askeri eğitim görevini icra etmekteyken, Türkiye'den de ordu mensupları Alman askeri akademisinde eğitim görmekteydi (Koçak, 1991, s. 45-48). İkili ilişkilerin en yoğun gerçekleştiği alan ise ekonomidir. $\mathrm{Bu}$ alanda yeniden yapılanma sürecinde bulunan Türkiye, ihtiyaç duyduğu yetişmiş insan gücü ve bilgi birikimini Almanya'dan tedarik yoluna giderek Cumhuriyetin ilk yıllannda önemli atılımlar gerçekleştirmiştir. Almanya ise ihtiyaç duydugu tarım ürünleri ve sanayisi için gerekli olan hammaddeyi Türkiye'den ithal ederek ihtiyaçlarını karşılama yoluna gitmiştir. Bu şekilde her iki tarafın da kazançlı çıktığı bir ekonomik ilişkiden bahsedilebilir.

\section{Mahmud Muhtar Paşa ve Mustafa Kemal Atatürk'ün Anılarında Türk-Alman İttifakı ve Rudolf Nadolny'nin Raporları}

1913-15 yllları arasında Osmanlı Devleti’nin Berlin Büyükelçiliği görevini yürüten Mahmud Muhtar Paşa'nın 1924 yllında Paris'te Fransızca yayınlanan, 1925 yllında ise Türkçeye aktarılan "Maziye Bir Nazar: Berlin Muahedesi'nden Harb-i Umumi'ye kadar Avrupa ve Türkiye-Almanya Münasebetleri”" eseri, TürkAlman İttifakı hakkında önemli bilgileri ihtiva etmektedir. Çalışma başlığından da anlaşılacağı üzere, 1878 Berlin Antlaşması'ndan Birinci Dünya Savaşı'na kadar yaşanan süreçte Osmanlı Devleti'nin Avrupa ve Almanya ile olan ilişkilerini konu edinen eser, Osmanlı Devleti'nin Alman İmparatorluğu ile ittifakının dışında farklı bir ittifak politikası, örneğin Rusya, İngiltere ve Fransa ile ittifakının mümkün olup olmadığı sorusuna da cevap aramaktadır. 
Muhtar Paşa, Birinci Cihan Harbi'nin başlangicina kadar olan süreçte Alman diplomat ve devlet adamlarının düşünce dünyasında Türkiye'nin bir iktisadi nüfuz sahası yahut bir taviz zemininden ibaret olduğunun altını çizmektedir. Von Jagow ve Bethmann-Hollweg gibi Alman diplomat ve devlet adamlarının Anadolu'nun nüfuz bölgelerine ayrılması planlarının hâlihazırda tartıştı̆̆ bir dönemde, önemli konularda Osmanlı Devleti ile dayanışma halinde olabilecek Rusya ile münasebetlerin daha da geliştirilmesi gerekliliğini vurgularken, harbin başlangıcıyla "O tehlikeli anın icaplarına uyarak, ortaya çıan büyük karışıklıklar içinde mahirane hareket ve her hususta da daima en büyük faydaların elde edilmesi" kanaatinde olduğunu belirtmektedir (Muhtar, 1999, s. 233). Osmanlı Devleti’nin takip edeceği en mühim siyasetin savaşın başlangıcında tarafsız kalınması olduğunu, fakat Balkan Savaşı ve Birinci Cihan Harbi arasında geçen kısa süre içerisinde ordunun 1slahı için atılan adımların arzulanan şekilde gerçekleşmemesi sebebiyle, bunun mumkün olmadığını, İngiltere'nin paraları ödenen ve imalatı tamamlanmış olan savaş gemilerinin Osmanlı donanmasına teslimatına yanaşmaması, Osmanlı Devleti'ni kaçınılmaz suretle İtilaf Devlerinin yanında savaşa sürüklemiştir (Muhtar, 1999, s. 243).

Mahmud Muhtar Paşa, savaşa giden süreçte Osmanlı ile İtilaf Devletleri arasındaki yakınlaşmayı imkansız kılan en önemli sebebi "Alman nüfuzunun başlıca dayanağı" olan Harbiye Nazırı Enver Paşa'nın himayesindeki Osmanlı askeri birliklerinin Alman tahakkümü altına girmesi şeklinde ifade etmiştir. Mahmud Muhtar Paşa, 1913'de Liman von Sanders'in ordunun sslahı için İstanbul'da göreve başlaması ve Breslau ve Goeben savaş gemilerinin Çanakkale üzerinden İstanbul'a sığınması ve akabinde Osmanlı donanmasına katılması suretiyle Alman Admirali Souchen'un kudret ve salahiyeti hepsinden üstün kilındı" cümlelerini sarfetmektedir (Muhtar, 1999, s. 248). 30 Ekim 1914 tarihinde donanmaya yeni katlan Alman savaş gemilerinin Rus liman şehirleri Odessa, Sivastapol ve Novosibirsk şehirlerini bombalaması artık ülkeyi dönülmez bir yola sokmuştur. Mahmud Muhtar’a göre Osmanlı devlet adamları Alman baskısından kurtulabilse idi, Alman gemilerini satın alma yoluna gider, sözde barışın devamı için İtilaf Devletlerinin Osmanlı Devleti'ne teklifine olumlu yanıt verir ve donanmada görevli Alman askeri personeli iade ederdi. Yalnız dönem hükümetinin bu konuda isteksiz davranması savaşı daha da kaçınılmaz kılıyordu (Muhtar, 1999, s. 252).

Osmanlı Devleti'nin Birinci Dünya Savaşı'na katılması konusunda bir çok farklı görüşün olabileceği gibi, hükümetin bunu ülke için en uygun şartlarda uygulamaya geçirmesi, belli başlı kazanımlar temin edilince de tam bir kararlılık göstererek harpten çekilme iradesini ortaya koyması gerekirdi. Fakat “Kafkasya'yı, Mısır'ı hatta Kırım’ı zaptetmek rüyalarına kapılan” hükümet, hata dolu başlangıca yenilerini ekleyerek askeri gücü sınırlı olan ordunun vatan savunmasını daha da zayıf düşmesine yol açtığını belirten Muhtar Paşa'ya göre “tedbirli davranarak bir savunma varziyeti benimsemekle iktifa edilmiş yahut münasip vakti gözetip uygun bir münferid barış için ele geçen firsatlardan istifade edilmiş olsa idi, müsbet neticeler alınabilirdi" (Muhtar, 1999, s. 256). 21 Şubat 1917 tarihinde Rusya, İngiltere ve Fransa arasında Osmanlı topraklarının taksimi üzerine imzalanan anlaşmanın, Ekim 1917‘de Sovyet Rusya’da meydana gelen Bolşevik ihtilali ile geçerliliğini yitirmesi üzerine İngilizlerin İstanbul'da temaslar kurmaya başladığını belirten Mahmud Muhtar Paşa, "genç Türk liderleriyle devam eden harpten faydalanan hempaların caniyane inatçlıkları" hiç bir teklifin kabul görmesine imkân vermemekteydi. Mahmud Muhtar Paşa şöyle devam etmektedir:

"Irkının selameti, yurdunun muhafazası için; milli ve siyasi istiklali, vatanın hürriyeti için o kıymetli kanını dökmek zaruretinde kalan kahraman Mehmetçik güya, Birinci Selim, Kanuni Süleyman devirleriymiş gibi, cihanın dört bir yanına serpilerek savaşması... O zavallı Mehmetçiğe Alsace- Laurenne'nin Hohenzoller (Alman) idaresinde kalması, yahut Germen nufuz tegallübunun Belçika'larda, Rusya'larda yayılması ve güçlenmesi için, amiyene tabirle, Pir aşkına pala çalındırıldı, taki zafer çelengi peşinde segirten bir iki serserinin şaşkınlık verici ve uygunsuz hallerinden kaynaklanan kuruntular uğrunda bir milyondan fazla seçkin vatan evladı hak-1 helake serildi ve şiddeti gittikçe artan büyük bir ittifak karşısında memleket müdafasız kaldı" (Muhtar, 1999 s. 263-264).

Osmanlı topraklarını Birinci Dünya Savaşı'nın sonunda dağılmaya ve çöküntüye mahkûm kılan yegane sebebi, II. Abdülhamid döneminden itibaren temelleri atılan "Türk-Cermen münasebetlerinin gelişmesinin sonucu olarak yorumlayan Mahmud Muhtar Paşa'ya göre dünya kendini: “Osmanlı Devleti'nin matemzede halkı yerine, zinde bir kavmin zebunkeş düşmanlarına karşı: "Osmanlı Devleti öldüyse yaşasın 
Türkiye!“ diye hayret verici bir güç ve ağırbaşlllıkla dikilerek zaferini ve gücünü ilan etmesi gibi harika karşısında bulmuştur” (Muhtar, 1999, s. 266).

Türk-Alman İttifakı'nın Mahmud Muhtar Paşa'nın kalemindem yorumlanışı üzerine, Nadolny ilk olarak 18 Şubat 1925 tarihinde Alman Dışişleri Bakanlığı'na bir rapor yazarak, bakanlık yetkililerini bilgilendirme yoluna gitmiştir. Nadolny raporunda, Mahmud Muhtar Paşa'nın savaş sırasında Alman Genel Kurmay Başkanlı̆̆ı'nın ricası üzerine görevinden alındığını, uzun yıllar Almanya'da yaşamış ve dolayısıyla Alman diline neredeyse bir Alman gibi hâkim olmasına karşın, ekseriyetle Türk-Alman ilişkilerini irdeleyen hatıratını özellikle Fransızca olarak Paris'te yayınlanmasının, yazarın derin bir Alman karşıt fikirlere sahip olduğunun bir göstergesi olarak algılanması gerektiğini ve hatıratını Fransız amaçlarına hizmet etmek için yazdığının altını çizmektedir. Nadolny ayrıca söz konusu raporunun sonunda olayların henüz tazeliğini koruduğunu belirtmiştir. Türkiye'de Birinci Dünya Savaşı dönemi Türk-Alman İttifakı'nı konu edinecek, önyargılardan uzak çalışmaların ortaya konması için daha zamanın bulunduğunu ve dönemin gelişmeleri ile alakalı bilgi ve belgelerin yayınlanmasıyla, Enver Paşa'nın öncülüğünde imzalanan Türk-Alman İttifakı'nın gerekliliği konusunun aydınlığa kavuşabileceğini ve Mahmud Paşa’nın vatanperver motifleri sıkça kullanması sebebiyle, Alman tarafindan, yayınlanan hatırata gereğinden fazla anlam yüklenmemesi gerektiğini bildirmektedir (PA AA, R78485, 18 Şubat 1925).

Bu başlık altında incelenecek diğer değerlendirme, Mustafa Kemal Atatürk'ün 12 Mart ile 12 Nisan 1926 tarihleri arasında Hâkimiyet-i Milliye ile Milliyet gazetelerinin başyazarları Falih Rifkı Atay ve Mahmut Soydan ile yaptığı yine bu iki gazetenin yanında Cumhuriyet gazetesinde de yayınlanan mülakatlarıdır. Burada, Atatürk’ün anılarının içeriğinin gün gün verilmesinden ziyade, genel hatlarıla TürkAlman İttifakı'na yaklaşımı ve ortaya attı̆̆ı iddiaları ele alınacaktır. Mülakatı derleyen Falih Rıfkı Atay'a göre, anılarda ismi geçen bazı Alman askeri yetkililerin kendileri ile alakalı savaş dönemine ait özel bilgilerin basın üzerinden ele alınmasından duydukları rahatsılıktan dolayı, Alman Büyükelçiliğinin ricası üzerine, Mustafa Kemal Atatürk’ün de anlayış ve nezaketiyle yayın 12 Nisan tarihinden itibaren durdurulmuştur (Görgülü, 1997, s. 14).

Atatürk’ün anıları genel hatlarıla, dönemin siyaset adamları ile olan karşılaşmaları ve bunlardan derlenen anekdotlanı, Itttihat ve Terakki Partisi'nin savaş öncesi ve esnasında yürüttüğü politikaları ve partinin liderleri hakkıdaki fikirleri, Şehzade Vahededdin’le gerçekleştirdiği, 15 Aralık 1917 ile 4 Şubat 1918 tarihlerini kapsayan, Alman Genelkurmay Başkanlı̆̆ ziyaretleri esnasında Alman İmparatoru II. Wilhelm ve üst düzey Alman generalleri ile olan görüşmelerinden kesitleri ve savaş döneminde görevli Osmanlı ordusunda yüksek mevkilerde görevli Alman subay ve general kadrosunun istisnai yetki konumunu kapsamaktadır (Görgülü, 1997, s. 5-10).

Mustafa Kemal Atatürk’ün 1926 yllındaki görüşlerine geçmeden, o tarihten yaklaşık 6 yll önce 10 Ekim 1919 tarihinde Mersinli Cemal Paşa için kaleme aldığı mektubundan savaş dönemi Türk-Alman İttifakı'nın oluşumu ve gelişimi ile alakalı -1926 yllındaki görüşlerine tamamlayıcı nitelikli bir katkı sağlayabilecekkesitler sunulacaktır. Atatürk mektubunda Mersinli Cemal Paşa'ya, savaş öncesi ittifak arayışlarında olan Türkiye için iki yol vardır diyerek devam eder;

"Ya Almanya ya da İtilaf Devletlerinin biriyle anlaşma yapacaktı."[...] Savaşa katılmamış olsaydık çok hoş olurdu. Ama katılmamaktan başka alternatif yoktu. Çünkü savaşa katılmamak silahlı bir tarafsızlı̆̆ı gerektiriyordu, yani boğazların kapatılmasını. Memleketimizin coğrafi yapısı, İstanbul'un stratejik durumu ve Rusya'nın İtilaf Devletleri arasında yer alması, bizim seyirci olarak kalmamıza müsade etmedi.[...] Özellikle İngiltere'nin gemilerimize el koyması ve donanma için toplanan 7,5 milyon parayı gasp etmesi, ayrıca İtilaf Devletlerinin savaş ilan etmesi,[...] ve son olarak Bolşevikler tarafından ilan edilen gizli antlaşmaya göre, İstanbul'un Çarlık Rusya'ya söz verilmiş olması bizi İtilaf Devletlerine karşı savaşmamızı gerektiren gerçeklerdi”' (Çalık, 1999, s. 225).

Türk-Alman İttifakı'nı politik ve stratejik zorunluktan ötürü meydana gelen bir hadise olarak pragmatist bir bakış açısıyla yorumlayan ve Cumhuriyet gazetesinde 15 Mart 1926 tarihinde "Birinci Dünya Harbinde normal olmayan durumumuz" başlıklı mülakatında ise Alman Askeri Misyonu çerçevesinde ve Birinci Cihan Harbi esnasında Osmanlı ordusunun kilit noktalarında görevli Alman subay ve komutanlara ordu yetki ve bilgilerinin "kayıtsız şartsız, bütün sırlanı ile verilmesinden ve teslim edilmesinden" ötürü üzüntüsünün altını çizen Atatürk, ortaya çıkan normal olmayan durumdan dolayı Almanlar ve Alman 
askeri heyetini eleştirmekten kaçınırken, asıl tenkit edilmesi gereken kişilerin Osmanli Devleti'nin reisi ve dönemin karar verici siyasilerinin olması gerektiğini belirtmiştir. Çünkü Atatürk'e göre Alman askeri heyetinin ayaklarına kadar giderek ve rica ederek orduda görevlendiren dönemin idarecileri, bu askeri heyete Türk milletinin kabiliyetsizliği ve beceriksizliğinden açık şekilde söz etmiş, "kendilerine adeta gelip bizi adam etmeleri teklif edilmiştir". Bu durum karşısında, imkânlanı ölçüsünde sesini ulaştırabileceği yüksek makamlara itirazda bulunmayı "vazife" sayan Mustafa Kemal, itirazlarına karşılık makul ve açık bir cevap alamadığını da aktarmıştır (Görgülü, 1997, s. 29).

Alman Büyükelçi Nadolny'nin Alman basınında yer almasından ve polemiğe evrilmesinden en çok çekindiği konu ise Yıldırım birlikleri komutanı Erich Falkenhayn'ın Gazi Mustafa Kemal'e 7 küçük kutu altın rüşvet teklifi konusunun Türkiye Cumhuriyeti Cumhurbaşkanı tarafindan yeniden gündeme getirilmesidir ki, bu meseleyi Mustafa Kemal mülakatında dile getirmiştir. Nadolny ve Alman Dışş̧̧leri Bakanlığı’nın konunun iki ülke basını tarafından muhtemel bir polemiğe dönüştürülmesi tehlikesinden dolayı çekinceleri olmasına rağmen Alman gazetelerinde Mustafa Kemal’in mülakatında geçen söylemleri üzerine yorumlar yer bulmaya başlamıştır. Dresdner Neueste Nachrichten Gazetesi 16 Nisan 1926 tarihinde "Kemal ve Almanlar", Rhenisch Westfälische Zeitung 24 Mart 1926 tarihinde "Mustafa Kemal'in Hatıratı. Almanya'ya bir uyarı", Deutsche Allgemeine Zeitung ise 1 Nisan 1926 tarihinde "Mustafa Kemal'in hatıratları. Almanya ve Türkiye", başlıklarıyla okuyucularını bilgilendirmişlerdir. Haberler içerisinde, Alman Dışişleri Bakanlığı Genel Sekreteri Carl von Schubert’i endişeye sevk eden ve iki ülke arasında ortaya çıkması muhtemel bir polemiği tetikleyecek nitelikte bir yazı olarak gördüğü yorum, 2 Nisan 1926 tarihinde Leipzige Neueste Nachrichten gazetesinde "Fransız-Türk Ankara Antlaşması. Alman Düşmanı Kemal Paşa” başlığıyla Alman okuyuculara duyurulmuştur. Bu yorumda Türkiye'nin Fransa ile imzaladığı dostluk antlaşmasından dolayı Alman politikacıların Türkiye'yi hâlâ bir müttefik ve dost ülke olarak göremeyeceği ve Türklerin eski silah arkadaşları olan Almanları, "sahtekâr ve ikiyüzlü" olarak tarif etmelerinin artık kabul edilemez bir durum olduğunun altı çizilmektedir (PA AA, R78486, 29 Mart 1926).

Mustafa Kemal'in Hâkimiyet-i Milliyye, Cumhuriyet ve Milliyet gazetelerinde 12 Mart-12 Nisan 1926 tarihleri arasında yayınlanan mülakatı, Büyükelçi Rudolf Nadolny tarafında günlük olarak yakından takip edilmekteydi. Mülakatın yayınlanmasından yaklaşık bir hafta sonra, Alman Dışşsleri Bakanlı̆̆ Genel Sekreteri Carl von Schubert'e yolladığ1, 19 Mart tarihli telgrafinda, yukarıda isimleri verilen gazetelerde Mustafa Kemal Atatürk'ün mülakatının yayınlanmaya başladığını iletmiştir. Nadolny, Mustafa Kemal’in mülakatın ilk günlerinde Birinci Dünya Savaşı'nda Alman General Erich von Falkenhayn'ın yolladığ1 altınlar ile kendisini etkisi altına alma çabasının nasıl başarısızlıkla sonuçlandığını gündeme getirerek Alman generali küçük düşürücü beyanatta bulunduğunu aktarmıştır. Nadolny, Mustafa Kemal'in Almanya'ya karşı herhangi bir düşmanlık beslemediğini, Almanlann Osmanlı ordusuna kendiliğinden gelmediklerini, aksine dönemin siyasileri tarafından davet edildiğinin özellikle altını çizmektedir. Alman Dışsşleri Bakanlığı tarafından uygun görülmesi halinde dikkatli bir şekilde mülakatın Almanya tarafinı ilgilendiren kısımları için Türk yetkililerle irtibata geçebileceğini söyleyen Rudolf Nadolny, böyle bir hamlenin ise Türk tarafinda ters tepki yapabileceği ihtimalinden dolay1, Mustafa Kemal Atatürk'ün de takip ettiği Deutsche Allgemeine gazetesinde 1lımlı bir haber yayınlatarak Alman basınında Gazi'nin Mülakatı üzerine çıabilecek gereksiz ve sivri dil kullanması muhtemel yayınlara karşı denge unsuru olması bağlamında teklifte bulunmuştur (PA AA, R78486, 19 Mart 1926).

29 Mart 1926 tarihli Nadolny'nin raporuna cevap niteliğindeki mektupta, Büyükelçinin fikir ve görüşlerinin Berlin'de de paylaşıldığını ve Deutsche Allgemeine Zeitung gazetesinde bahsi geçen mülakat üzerine özet bir yazısının yayınlanabileceğinin de altını çizen Dışişleri Bakanlığı Genel Sekreteri Carl von Schubert sadece Rheinische-Westfälische Nachrichten ve Hamburger Nachrichten gazetelerinde "Gazi'den Almanya'ya Uyarı" başlıklı yorumların yayınlandığını söylemektedir. Von Schubert, Türkiye'de Cumhuriyet'in ilanıyla yeni bir politik eğilimin ortaya çıtığının altını çizmektedir. Özellikle Türkiye'nin son dönem politikalarında Fransa'ya karşı olumlu bir yaklaşım hâkim olduğunu, öyle ki bir Fransız askeri yetkilinin Pankaltı'ndaki askeri okulda düzenlenen yıl dönümü etkinliklerinde Türk yetkililer tarafindan onurlandırılışı ve savaş döneminde Osmanlı ordusunda görevde bulunmuş askeri heyet hakkında yapılan yorumlarla, Atatürk'ün Paris'te gerçekleştirilecek Suriye görüşmeleri öncesi Fransız hükümeti nezdinde 
Türk tarafı için uygun bir ortam oluşturma çabası içinde olduğunu da vurgulamaktadır (PA AA, R78486, 29 Mart 1926).

Mart sonunda görüşmelerde bulunmak üzere Ankara’ya giden bulunan Rudolf Nadolny, 1 Nisan günü Dışişleri Bakanlığı’na yolladığı raporunda, Mustafa Kemal Atatürk'ün genel sekreteri Albay Mehmet Tevfik Bıyıklıŏlu ile yüz yüze görüşme gerçekleştirmiştir. Bıyıklığlu bu görüşmede Nadolny'e, Gazi’nin mülakatından herhangi bir politik amaç ve çıkarım beklememekle beraber, bunun sadece Cumhurbaşkanının kişisel tecrübelerinin yayınlanması olarak görülmesi gerektiğini vurgularken, Alman General Falkenhayn tarafindan Atatürk'e yollanan para konusunda ise, kendisinin o dönem yaşanan olaya tanıklık etmemiş olması hasebiyle ve dışarıdan gözlemlediği kadarıyla ordunun ihtiyaçlarının karşılanması için yollanan bir para olduğunun garantisini vermiştir. Bıyıklığlu ayrıca Cumhurbaşkanı Mustafa Kemal Atatürk aracılığyla, Alman ordusu hakkında söyleyeceği dostane cümleler ile gerginleşen ortamı yeniden iyileştirme yolunda çaba harcamaya hazır olduğunu belirtmiştir (PA AA, R78486, 1 Nisan 1926).

Konu ile alakall, Dışişleri Bakanllğı ile Alman Büyükelçiliği arasındaki son yazışma ise mülakatın yayınlandığı son gün olan 12 Nisan tarihlidir. Bu raporda Rudolf Nadolny, şuana dek yayınlanan bölümlerde mülakatın tarihi ve politik olaylar ve gelişmeler konusunda kendileri için pekte mühim bilgiler sunmadığını ve Cumhurbaşkanı Genelsekreteri Tevfik Bıyıklığlu ile yeni bir görüşme daha gerçekleştirdiğini, Gazi'nin Genelsekreteri aracillğıyla Nadolny'e nezaket çerçevesinde sormak suretiyle, Alman tarafinın Mustafa Kemal'den neler yazmasını arzu ettiklerini bildirmelerini istemiştir. Nadolny ise diplomatik bir dille Gazi'nin doğru cümleleri bulacağına olan inancının tam olduğunu vurgulayarak, görüşmenin sonlandığını yazmıştır (PA AA, R78486, 12 Nisan 1926).

\section{Sonuç}

Birinci Dünya Savaşı'nda, Türk-Alman İttifakı'nın kilit noktalarında görev almış diplomat ve subayların yayınladıkları eserler, gündeme getirdikleri iddialar ve yorumlar, 1920’li ylllardan itibaren iki ülke arasında gerçekleşen ortak yakın tarih tartışmalarının ana ekseninde yer almıştır. Türk-Alman İttifakı, Türkiye Cumhuriyeti'nin kuruluşunun ilk yllarından itibaren savaşta aktif rol oynayan asker, diplomat ve politikacıların hatıratlarında farklı perspektiflerden yorumlanmıştır. Mustafa Kemal Atatürk'ün mülakatı ve Mahmud Muhtar Paşa'nın hatıratında ittifakın ana hatlarılla nasıl ele alındığının ve hangi motiflerin ön plana çıkartıldığının tespit edildiği bu çalışmamızda, ayrıca Alman Dışişleri Bakanlığı ile İstanbul'daki Alman Büyükelçi Rudolf Nadolny arasındaki yazışmalarda Türkiye'de oluşan bu yeni algının nasıl yorumlandığı konusu üzerinde durulmuştur.

Mustafa Kemal Atatürk gibi Muhtar Paşa'da, Türk-Alman İttifakı'nın dönemin askeri ve politik gelişmeleri dikkate alındığında Osmanlı Devleti için kaçınılmaz bir tercih olduğuna inanmaktadır. Fakat savaş öncesi ittifak kararının Enver Paşa tarafindan tek başına verilmiş olması ve savaşın başlangıcıyla beraber- Osmanlı Devlet adamlarının isteği ve onayı çervesinde- Osmanlı ordusunun, ordu kararlarının Alman askeri heyet mensupları ve generallerin tercihlerine terk edildiğininin ve ordu içerisinde alınan kararların milli menfaatlere uygun olmadığının alıını çizmektedir.

3 Mart 1924 tarihinde imzalanan Türk-Alman Dostluk Antlaşması'nın onaylanmasıyla aynı yıllın Haziran ayında görevine başlayan Büyükelçi Rudolf Nadolny, Almanya’ya karşı Türkiye'de Birinci Dünya Savaşı özelinde oluşan olumsuz müttefiklik algısı üzerine Alman Dışişleri Bakanllğı’nı bilgilendirmiş, Cumhurbaşkanı Genelsekreteri Tevfik Bıyıklıoğlu ile irtibat kurarak Kemal Atatürk’ün hatıratı ile alakalı Alman basınında çıkabilecek olan ve iki ülke ilişkilerinde krize yol açabilecek gerginliklerin önüne geçmeyi başarmıştır. Mustafa Kemal Paşa’nın mülakatında Osmanlı ordusunda görevli Yıldıım Ordular Grubu komutanı Alman General Erich von Falkenhayn ve Alman askeri misyonu çercevesi hakkındaki tecrübe ve fikirlerinin yayınlanmasıyla Almanlara karşı herhangi bir düşmanlık amaçlamadığının, Alman Büyükelçiye bildirmesiyle, Alman Dışş̧̧leri Bakanlığı dönemin siyasi atmosferinden ötürü Gazi Mustafa Kemal’in düşünce ve fikirlerini anlayışla karşıladığı görülmüştür. Rudolf Nadolny, Mahmud Muhtar Paşa'nın hatıratını ise yazarın anadili seviyesinde Almancaya hâkim olmasına karşın Paris'te yayınlanması ve savaş dönemi Fransa politikalarinı eleştirmemesi sebebiyle, pekte ciddiye alınmaması gereken, savaş dönemi bilgilerin daha netliğe kavuşmadığından dolayı erken yazılmış ve politik ve askeri gerçeklikten uzak bir hatırat olduğunu vurgulamaktadır. 
$\mathrm{Bu}$ makelede incelenen hatırat ve mülakatı hangi bağlamda ele almak gerekmektedir? Makalemizin kapsamında incelenen kaynaklardan yola çıkarak ortaya atılan iddiaları gelişim aşamasında olan bir ulus devletin tarih yazımının bir parçası olarak yorumlayabiliriz. Bu yeni ulusun lideri de, yakın tarihi geçmişi inşa ederken tarihin dönüm noktalarını kendi bakış açılarından ve kendilerine pay çıkaracak şekilde yorumlama yolunu seçmiştir. Milli aidiyet duygusunun pekişmesinde yeni bir ulus devlet inşaa edilirken mümkün olduğunca mağlubiyetler göz ardı edilmiş, galibiyetler ise ön plana çıkartılmış ve bir önceki yönetimin siyasi tercihleri ise iktidardakiler tarafından eleştiri oklarının hedefine konmuştur.

\title{
5. Extended Abstract
}

The works published, the claims and comments made by diplomats and officers who took part in the key points of the Turkish-German alliance in the First World War have been the main axis of the common history debates between the two countries since the 1920 s. Since the first years of establishment of the Republic of Turkey, the Turkish-German alliance has been interpreted from different perspectives in the memoirs of soldiers, diplomats and politicians who played an active role in the war. In our study, how the alliance was outlined and which motifs were brought to the forefront were determined with the interview of Mustafa Kemal Atatürk, who had important duties in the Ottoman army and diplomacy during the war, and with the memoirs of Mahmud Muhtar Pasha. Our study also focused on how was the interpretation of this new perception in Turkey in correspondence between the German Ambassador in Istanbul with the German Foreign Ministry, Rudolf Nadolny. Like Mustafa Kemal Atatürk, Muhtar Pasha believes that the Turkish - German alliance was an inevitable preference for the Ottoman within the military and political developments of the period. However, the fact that the desicion of the alliance before the war was made by Enver Pasha alone -with the request and approval of the Ottoman statesmen,and he underlines that with the beggining of the war the decisions of the Ottoman army were abandoned to the preferences of the members of the German military delegation and the generals, and that decisions that taken within the army were not in line with national interest.

Ambassador Rudolf Nadolny, who started his duty in June of the same year with the approval of the Turkish - German Frienship Treaty signed on 3 March 1924, has informed the German Ministry of Foreign Affairs on the negative perception of alliance against Germany in the First World War. By contacting the President's Secretary General Tevfik Byylkoğlu, he succeeded in preventing the tensions that might appear in the German press about the memoirs of Kemal Atatürk and that could lead to a crisis in the relations between the two countries. He informed the German Ambassador that in the interview of Mustafa Kemal Pasha, he did not aim at any hostility against to Germans with the publication of his experiences and ideas about German General Erich von Falkenhayn, who was in the Ottoman army as the commander of the Yildırım Army Group, and the framework of the German military mission. On this occasion, it was seen that the German Foreign Ministry understood the thoughts and ideas of Ghazi Mustafa Kemal due to the political atmosphere of the period. Rudolf Nadolny emphasize that the memoirs of Mahmut Muhtar Pasha, on the other hand, are unrealistic because they were published in Paris despite the author knew German at the level of his native language and does not criticize the policies of wartime France. He also emphasizes that the memorial was early written when the war informations was not clearer, thats why it is far from political and military reality.

In what context should the memoirs and interviews examined in this article be taken into account? Based on the sources examined within the scope of our article, we can interpret the claims made on both the Turkish side and the German side as a part of the historiography of the two nation-states that are at the stage of establishment. While these two new nations construct their recent historical past, they have chosen to interpret the turning points of history from their own perspective and in a way that gives them credit. While building a new nation-state in the consolidation of the sense of national belonging, defeats were ignored as much as possible, victories were highlighted, and the political preferences of the previous administration were put at the target of crictism by those in power

\author{
Kaynakça \\ Arşiv Belgeleri \\ Federal Almanya Dışişleri Bakanlığ1 Diplomatik Arşivi
}


(Politisches Archiv des Auswärtigen Amtes- PA AA)

PA AA/ R78485

PA AA/ R78486

Yayınlanmış Eserler

Aksakal, M. (2010). Harb-ı Umumi Eşsiğinde Osmanlı Devleti Son Savaşına Nasıl Girdi. İstanbul: Bilgi Üniversitesi Yayınları.

Alkan, N. \& Eyyub Ş. (2018). Savaşanlarn Gözüyle Türk-Alman Ittifakı (1914-1918). İstanbul: Kronik Kitap.

Alkan, N. (2020). İmparatorluğun Son Savaşı. Birinci Dünya Savaşı'na Neden ve Nasıl Girdike? İstanbul: Timaş Yayınları.

Alkan, N. (2007). II. Abdülhamid Devrinde İstihdam Edilen İlk Alman Askerî Heyetinin Komutanı Otto von Kaehler ve İki Tarafin Beklentileri', İstanbul Üniversitesi Edebiyat Fakültesi Tarih Dergisi, (43), 135165.

Alkan, R. (2011). Die politischen Beziehungen zwischen Deutschland und der Türkei während der Weimarer Zeit 1918-1933. Yayınlanmamış Yüksek Lisans Tezi, Albert Ludwigs Üniversitesi Felsefe Fakültesi, Yakınçağ Avrupa Tarihi Bölümü, Freiburg.

Avc1, M. (2014). Die türkisch-deutschen Wirtschaftsbeziehungen in den Jabren von 1923 bis 1945 unter Beachtung der politischen Entwicklungen. Yayınlanmamıs Doktora Tezi, Aachen Teknik Üniversitesi.

Çalık, R. (1999). Alman Kaynaklarına Göre Cemal Paşa. Osmanlı Araştırmaları, (19), 223-254, İstanbul.

Görgülü, İ. (1997). Atatürk’ün Anlar. Büyük Gaz̧miz̨n Büyük Hayatından Hatıralar. Ankara: Bilgi Yayınevi.

Hanioğlu, Ş. M. (1995). Enver Paşa. Türk Diyanet Vakfi İslam Ansiklopedisi, (11), 261-264, İstanbul.

Kannengiesser, H. (2009). Çanakkale'de Türklerle Beraber. Bir Alman Albaymm Gözünden Canakeale. İstanbul: Timaş Yayınları.

Karabekir, K. (2001). Tarih Boyunca Türk - Alman İlişkileri. İstanbul: Emre Yayınları.

Koçak, C. (1991). Türk-Alman İliskileri (1923-1939). İki Dünya Savaşı Arasindaki Dönemde Siyasal, Kültürel, Askeri ve Ekonomik İliskiler. Ankara: Türk Tarih Kurumu Basımevi.

Mangold-Will, S. (2013). Begrenzte Freundschaft. Deutschland und die Türkei 1918-1933. Göttingen: Wallstein.

Mejcher, H. \& Schmidt-Dumont, M. (2010). Franz Frederik Schmidt-Dumont. Von Altona nach Ankara. Ein hanseatisches Leben im Vorderen Orient (1882-1952). Münster: LitVerlag.

Muhtar, M. (1999). Mariye Bir Nazar. Berlin Muahedesinden Harb-ı Umumi'ye kadar Avrupa ve TürkiyeAlmanya Münasebetleri. İstanbul: Ötüken Neşriyat.

Mühlmann, C. (1998). Canakkale Savaşı: Bir Alman Subayının Notlar. İstanbul: Timaş Yayınları.

Schönig, C., Çalık, R. \& Bayraktar, H. (2012). Türkisch-Deutsche Beziehungen: Perspektiven aus Vergangenheit und Gegenwart. Berlin.

von Sanders, L. (2006). Türkiye'de Bess Sene. İstanbul: Yeditepe Yayınlar1.

Ziemke, K. (1930). Die neue Türkei. Politische Entwicklung 1914-1929. Stuttgart. 